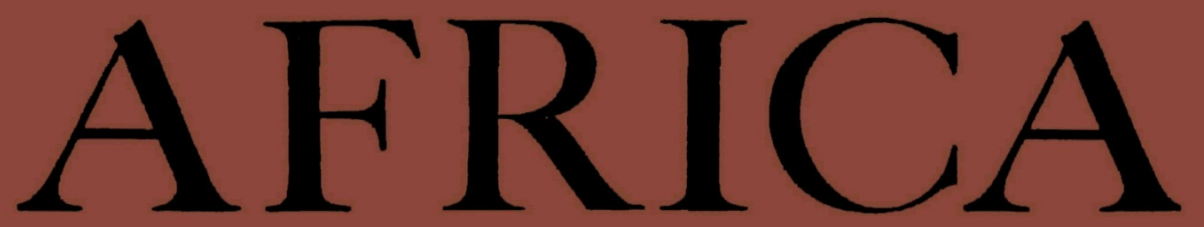

JOURNAL OF THE.

INTERNATIONAL AFRICAN INSTITUTE

JOURNAL DE

L'INSTITU'T IN'TERNATIONAL AFRICAIN

ZEI'TSCHRIFT DES

INTERNATIONAI.EN AFRIKANISCHEN INSTITUTS

\author{
Eivitor \\ DARYLL FORDE \\ Assistant Editor \\ B. E. WYATT
}

LONDON

OXFORD UNIVERSITY PRESS

GEOFFREY CUMBERLEGE 


\section{CONTENTS OF THIS NUMBER}

PATTERNS OF AUTHORITY IN WWST AFRICA Paula Brom page

THE AGE-SET SYSTEM OF THE PASTORAL POKOT

J. G. Peristiany

279

SOME NOTIONS OF WITCHCRAFT AMONG THE DINKA Godfrey Lienhardt

AN ANNOTATED BIBLIOGRAPHY OF AFRIC $A N$ AND AFRICANDERIVED MUSIC SINCE ${ }_{1936}$ Alan Merriam

CONTRIBUTORS TO THIS NUMBER

CURRENT RESEARCHES IN AFRICAN ETIINOLOGY AND LINGUISTICS

BACK NUMBERS OF AFRICA

NOTES AND NEWS

I.E FUTUR MUSÉE HISTORIQUE DE L'A.O.F.; HIGHIR ELUCATION IN THE BRITISII COLONIES; EDUCATIONAL REVIEW IN BRITIBH AFRICAN TFRRTTORIES; SUIDAN PUBLICATIONS BUREAU; SUDAN LITERACY CAMPAIGNS; LOCAL GOVERNMFNT IN EASTER.N NIGERIA ; AIYETORO: A PIONEIR COMMUNITY DEVHLOPMENT PROJECT; COPPERRIIT: CONFERENCE ON SUCIAL, WELFARE; J. RICHARD-MOLARD.

\section{REVIEWS OF BOOKS}

NATIVE ADMINISTRA TION IN THE RR TTISH COLONIES IN ATRICA, by Lord Hailey (L. Mair); TONI: LANGUAGES : A TLCHNIQLE FOR DETERMINING THF: NLMBER AND TYPE OF PITCH CONTRAstS in A I.ANGUAGE, by Kenmeth L. Pike (W. J. Samarin); tiIE Blessi.d MISSIONARIES, by Edwin $\mathbb{W}$. Simith (F. Longland); sTuDIis IN APpLICD ANTIiRopol.agY in kenYa, by Philip Mayer (L. P. Mair); West Aphican PSYChology, by G. Parrinder (G. I. Jones); sculpture of negro africa, by Paul S. IT'ingert (G. I. Jones).

BIBLIOGRAPHY OF CURRENT LITERATURE DEALING WITH AFRICAN LANGUAGES AND CULTURES 